NALS
JOURAL

\title{
VERB PLACEMENT VARIATION IN SWEDISH AND DANISH
}

\author{
MAUD WESTENDORP
}

\section{ABSTRACT}

This article gives a summary of the Swedish and Danish data on verb placement in the Nordic Word order Database (NWD; Lundquist et al. 2019). The data were collected using an elicited production paradigm. I discuss variation in verb placement in Danish in four constructions: in embedded clauses with respect to adverbs (embedded V2), in main clauses with respect to preverbal and sentence-medial adverbs, and in embedded and main clause wh-questions. The Swedish data cover embedded clauses only. The Swedish and Danish results are discussed in direct comparison to the verb placement patterns observed in the other North Germanic languages covered in the NWD.

\section{[1] INTRODUCTION}

Swedish and Danish are verb second (V2) languages: in main clauses, the finite verb is in second position, whilst embedded clauses by default have non-V2 order. Since the standard word order of both languages is SVO, the V2-property is not unambiguously manifested in subject-initial clauses. The non-subject initial main clause in (1) and the clause in (2) with the sentence-medial adverb aldrig 'never' are however unambiguously V2. Here the finite verb has moved out of the VP, to a position in the left periphery, as indicated by the subject-verb inversion in (1) or the Verb > Adverb order in (2).

(1) Igår gick hon till sitt arbete.

[Swedish]

yesterday went she to poss work

'Yesterday, she went to her work.'

(2) Han pakker aldrig sin kuffert i tide.

he packs never poss suitcase in time

'He never packs his suitcase on time.'

For the sake of convenience I will assume a fairly standard model of phrase 
structure in this article, where the clause is divided into three domains: the verbal domain (VP), the inflectional domain (IP), and the C-domain (CP), where features relating to finiteness, clause type, and illocutionary force are found. I adopt an analysis of verb second developed out of the seminal work of den Besten (1983), by which the verb moves to C, through I.

Despite being V2-languages, certain Swedish and Danish main clauses can have non-V2 order, e.g., in the presence of a specific type of "preverbal" adverb. These adverbs are available in all Mainland North Germanic languages and can be placed before the finite verb in main clauses which linearly results in non-V2 order as in (3) (see Brandtler \& Håkansson 2017, Julien 2018, Lundquist 2018 for discussion of these adverbs in Swedish and Norwegian).

(3) Han nästan grät av glädje.

[Swedish]

he almost cried of happiness

'He almost cried with joy.'

Swedish and Danish embedded clauses are non-V2. The embedded verb remains in situ and follows sentence-medial adverbs, as in the Swedish embedded whquestion in (4) or the Danish relative clause in (5).

(4) Kalle frågade [vart Anna alltid cyklar i helgen.] [Swedish] Kalle asked where Anna always bikes in weekend.DEF 'Kalle asked where Anna always bikes in the weekend.'

(5) Det her er caféen [som jeg altid spiser croissant på.] [Da.] this here is café.DEF that I always eat croissant on 'This is the café where I always eat croissants.'

Some embedded clauses however allow for main clause word order (i.e., Verb > Adverb). Examples of embedded clauses with this order in Swedish and Danish are given in (6-7) (cf. (4-5)).

(6) Kalle sa att Anna cyklar alltid till arbetet. [Swedish] Kalle said that Anna bikes always to work.DEF 'Kalle said that Anna always bikes to work.'

(7) Mads siger, at han barberer sig altid om morgenen. [Da.]
[ Mads says that he shaves REFL always at morning.DEF 'Mads says he always shaves in the morning.'

Whereas Icelandic has a generalised V2 pattern in embedded clauses, the 
Mainland North Germanic (MNG) languages only allow so-called embedded verb second (EV2) in a restricted set of clauses. The difference between these languages is often stated as a difference between V-to-I (Icelandic) and optional embedded V-to-C movement (MNG). Independent V-to-I movement was lost completely in Swedish and Danish around 300 years ago (see e.g., Falk 1993: 155f., Vikner 1995: 151, Sundquist 2003). Since Andersson (1975), the possibility of having verb second order (i.e., Verb > Adverb) in embedded clauses, has been linked to some notion of assertion (see e.g., Bentzen et al. 2007, Julien 2007 and Wiklund et al. 2009, Gärtner 2019). This means that only clauses with a specific semantics allow for optional V-to-C movement in MNG.

The word order patterns presented in (3-7) have been extensively discussed in the literature on North Germanic. In this article, I contribute to this discussion by presenting the results of two production experiments that elicited spoken production of Swedish embedded clauses and Danish main and embedded clauses. The results from the two experiments show that embedded V2 is produced only to a very limited extent in both languages, and that V3 in main clauses is rare in Danish in contexts where it should in principle be possible.

The structure of this article is as follows: the next section reviews some relevant background literature and sets up predictions for the experimental outcomes. In Section 3, I present the methodology for eliciting spoken production. In Section 4, I discuss the results for the Swedish and Danish embedded clause conditions. As will become clear, the results are similar for the two languages, and I will therefore discuss them together. Section 5 focusses on the main clause results from Danish. Finally, I discuss the results in Section 6, comparing the Swedish and Danish results to verb placement patterns in other North Germanic varieties (i.e., Norwegian and Faroese).

\section{[2] VARIATION IN VERB PLACEMENT IN SWEDISH AND DANISH}

The article explores verb placement variation in four constructions: in embedded clauses with respect to adverbs (embedded V2), in embedded whquestions, in main clauses with respect to preverbal and sentence-medial adverbs, and main clause wh-questions. The method used in the study has developed gradually, and the Swedish experiment therefore includes only embedded clauses, not main clauses. The Danish experiment is an extension of the Swedish experiment and includes all four constructions listed above. In this section, I give a background to the variable verb placement patterns in Swedish and Danish embedded clauses, and in Danish main clauses. 


\section{[2.1] Variation in Swedish and Danish embedded clauses}

As mentioned above, Swedish and Danish have lost the possibility of independent V-to-I movement (e.g., Falk 1993, Vikner 1995, Sundquist 2003). In MNG, embedded verb second (EV2) is only possible in a restricted set of clauses and is standardly assumed to be the result of embedded V-to-C movement. That is, it can be represented as in (8a), as opposed to ( $8 \mathrm{~b})$, which is string-identical but the result of V-to-I movement.
(8)
a. $\quad\left[{ }_{\mathrm{CP}} \mathrm{sub} \mathrm{V}_{\text {fin }}\right.$
IIP $_{\text {sub }} t_{V}$
[vp neg/adv
[IP $\mathrm{sub} \mathrm{V}_{\text {fin }}$
[vp neg/adv
$\left[\mathrm{vp} \ldots \mathrm{t}_{\mathrm{v}} \ldots\right.$

Since the derivation in (8b) is not available in Swedish and Danish, the word order Verb > Adverb can be used as a diagnostic for EV2. The semantic environment licensing embedded V2 in Swedish is sometimes described as a "declarative core" (Teleman et al. 1999, vol. 4). In other words, it is first and foremost possible when the embedded clause "depicts what someone thinks, knows, understands or says" (1999, vol. 4: 537). Allan et al. (1995: 519) similarly describe Danish embedded clauses with Verb > Adverb as "reported speech" (see e.g., (6-7)). Without the possibility of the complement being asserted, such as after the verb tvivla 'doubt' (9), embedded V2 is generally thought to be disallowed or at least dispreferred (see Wiklund et al. 2009: 1920 for Norwegian and Swedish, Heycock et al. 2010: 86 for Danish).

(9) * Han tvivlar på att... [Wiklund et al. 2009: 1919, (23a)]
he doubts on that
Hon har inte träffat den här mannen.
she has not met this here man.DEF
'He doubts that she has met this man.'

EV2 has been shown to be restricted in written registers but more common in the spoken registers of MNG. Prescriptive grammars of both Swedish and Danish advice against the use of this construction in written language (Teleman et al. 1999, vol. 4: 358, Lundskær-Nielsen \& Holmes 2011: 220).

Interestingly, the type of adverb also seems to play a role in the possibilities for embedded Verb > Adverb order in several varieties of North Germanic. For Northern Norwegian, for example, it has been argued that the embedded finite verb can move over adverbs, but not to the left of negation (Bentzen 2005, Wiklund et al. 2007). Heycock et al. (2010) likewise show that embedded verb movement past adverbs in Faroese is more accepted than movement past negation. In the same experiment, Heycock et al. find that this was not the case 
in Danish, however (2010: 84). Similar differences between verb movement past negation and other adverbs have also been found for the Fenno-Swedish dialect of Kronoby (Northern Ostrobothnian) (Platzack \& Holmberg 1989, Wiklund et al. 2007: 216). Further differences in movement possibilities have been found between different adverbs: in both Faroese and Northern Norwegian, embedded Verb $>$ Adverb order tends to be rejected with adverbs always and never (Bentzen et al. 2009: 85f.) but accepted with ofte (Wiklund et al. 2007: 204-5).

In contrast to assertive embedded clauses, embedded wh-questions in Swedish and Danish always have Subject $>$ Verb word order. This is the case both when the subject is the wh-word (10/11a) and when it is a separate pronoun or phrase (10/11b).

(10) a. Kalle undrade ... vem som vann tävlingen igår. [Swe.] Kalle wondered who cOMP won match.DEF yesterday 'Kalle wondered who won the match yesterday.'

b. Hon ville veta ... vilken film (som) eleverna såg. she wanted know which film COMP students.DEF saw 'She wanted to know which film the students saw.'

(11) a. Ellen spurgte, hvilke bands der spillede på festivalen. [Da.] Ellen asked which bands cOMP played on festival.DEF 'Ellen asked which bands played at the festival.'

b. Mads spurgte, hvor mange fisk (*der) Elias fik. Mads asked how many fish comP Elias got 'Mads asked how many fish Elias got.'

The complementizer som (Sw.) or der (Da.), otherwise found in relative clauses, is obligatory in subject wh-questions (10/11a). In Swedish, insertion of the complementizer is optional when the wh-element is not the subject (10b). This variation is dependent on register, dialect and the syntactic properties of the surrounding elements (Teleman et al. 1999/4: 555f., see also Stroh-Wollin 2002: 50f.). In Danish, insertion of der is ungrammatical in non-subject wh-questions (11b; see Hansen \& Heltoft 2011: 1496).

\section{[2.2] Variation in Danish main clauses}

As stated in the introduction to this article, Danish declarative main clauses standardly have verb second (V2) word order. Certain "preverbal" or "V3triggering" adverbials, however, optionally occur in second position in the clause between a clause-initial element and the finite verb as in (12a). Only a subset of adverbs can be placed in this position; other sentential adverbs 
including negation cannot occur preverbally (12b-c).

(12) a. Hun ligesom grinede af ham. [Jørgensen 2014: 97, (6)]
she like laughed of him
'She, like, laughed at him.'
b. * Hun alligevel grinede af ham. [Jørgensen 2014: 97, (6b)]
she anyhow laughed of him
'She laughed at him anyway.'
c. * Hun ikke grinede af ham.
she not laughed of him
'She didn't laugh at him.'

Despite the apparent non-V2 word order of (12a), sentences with preverbal adverbs have been argued to involve V-to-C movement (Brandtler \& Håkansson 2017, Julien 2018, Lundquist 2018). Subject-Verb inversion in non-subject initial clauses with preverbal adverbs suggests that this is likely to be the case:
(13) I går
ligesom grinede hun af ham.
[Danish, yesterday
like laughed she of him C. Sant, p.c.] 'Yesterday, she sort of laughed at him.'

Adverbs that can occur in preverbal position are found in all varieties of Mainland North Germanic. In Norwegian and Swedish, this set of adverbs is quite large and non-V2 order with these adverbs is common (see e.g., Brandtler 2020 for a review of Swedish corpus data). For Danish, on the other hand, it has been claimed that V3-adverbs are very infrequent, and that only a few Danish adverbs can occur in preverbal position (Nimb 2004: 153). Based on the distribution and specific semantics of Danish preverbal adverbs, Nimb argues that preverbal adverbs must strictly modify the following element and can never scope over the entire sentence in Danish (Nimb 2004: 101-4, see also Jørgensen 2014: 97). In this respect, Danish preverbal adverbs differ from their Swedish counterparts. Both Lundquist (2018) and Brandtler (2020) suggest that Swedish preverbal adverbs can function either as constituent adverbials or as adverbials that modify the entire clause.

Verb placement variation in main clause wh-questions is commonplace in many Norwegian dialects (see Lohndal et al. 2020: 778-782 for a short overview; or Westendorp 2021 for discussion of results in the NWD). In Danish (and Swedish), on the other hand, wh-questions are standardly verb second (Allan et al. 1995: 494). This is the case for both subject and non-subject wh-questions (i.e., questions where the wh-element is an adjunct or object). The only exception to 
standard V2 word order in this construction in Danish is the possibility of inserting the "subjective" particle mon expressing uncertainty, which can follow the wh-element (Hansen \& Heltoft 2011: 1594-5). Optionally, the complementizer der can follow this particle:
Hvis hund mon (der) vinder udstillingen? which dog mon COMP wins exhibition.DEF 'Which dog do you think will win the exhibition?'
(H\&H 2011: 1594)

\section{[3] METHODOLOGY}

To get a better understanding of the different possible exceptions to the standard V2 pattern in Swedish and Danish, two elicited production experiments were set up. The methodology of this study developed successively, and conditions and items were therefore added, changed and removed over the course of the data collection. As a consequence, the Danish experiment includes more experimental conditions than the Swedish counterpart. Table 1 gives an overview of the experiments discussed in this article. These experiments are part of the larger research project developing the Nordic Word order Database (NWD). ${ }^{1}$ Similar experiments were conducted on the Faroe Islands and in (Northern) Norway. I will compare the results of the Swedish and Danish experiments with the other data in the database in Section 6.

\begin{tabular}{ccccc}
\hline Language & Syntactic structures & $\begin{array}{c}\text { \# of } \\
\text { speakers }\end{array}$ & $\begin{array}{c}\text { Gender } \\
\text { (male/female) }\end{array}$ & $\begin{array}{c}\text { Age range } \\
\text { (mean) }\end{array}$ \\
\hline Swedish & $\begin{array}{c}\text { embedded clauses (EV2 and } \\
\text { embedded wh-questions) }\end{array}$ & 21 & $10 / 11$ & $\begin{array}{c}16-51 \\
(22.4)\end{array}$ \\
Danish & $\begin{array}{c}\text { embedded clauses + } \\
\text { main clauses (preverbal } \\
\text { adverbs and wh-questions) }\end{array}$ & 12 & $4 / 8$ & $\begin{array}{c}17-70 \\
(27.3)\end{array}$ \\
\hline
\end{tabular}

TABLE 1: Overview of experiments and participant groups.

[1] The Nordic Word order Database (NWD) is a collaboration between researchers from the University of Oslo and UiT The Arctic University of Norway. The experimental paradigm discussed in this article was developed by Björn Lundquist and Maud Westendorp. The motivations, design, and material of the experiments for the NWD-project are described in greater detail in Lundquist et al. (2019). The materials were checked by native speakers, and several other researchers and research assistants helped with the data collection and analysis (see Acknowledgements). 


\section{[3.1] Participants}

The experimental sessions were recorded in three locations in the greater Stockholm area (Stockholm and Sollentuna), and two locations in the Capital Region of Denmark (Copenhagen and Fredriksværk) (see Figure 1).

28 participants were recorded in the Swedish experiment. Of these, 21 speakers were native speakers of Swedish (one of the native Swedish speakers is a Swedish-Dutch simultaneous bilingual); the other speakers were all second language speakers of Swedish. Only the L1 speakers are included in the online NWD-database and discussed in the results section in this article; cf. Table 1 above. The participants were recruited through contacts at high schools in the Stockholm area

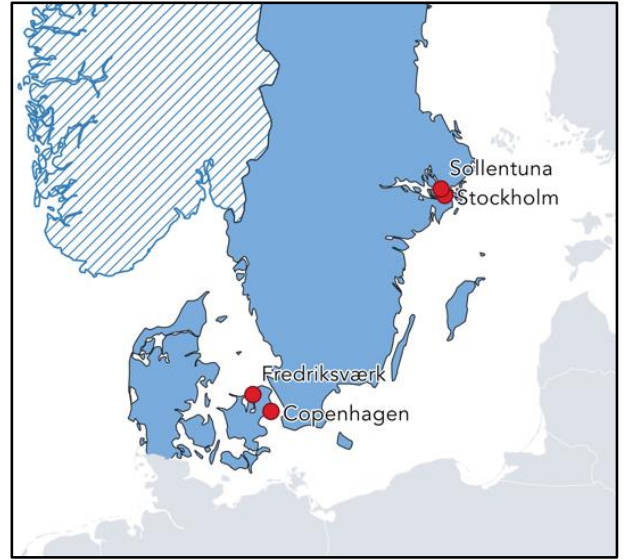

FIGURE 1: Overview of fieldwork locations in Sweden and Danmark. (approached via a Facebook page for Swedish teachers), and at Stockholm University. The high school students that participated received a small thank you gift, all adult participants were compensated for their time with a movie gift card.

The Danish participants were recruited via personal contacts, a Facebook page for high school teachers and through contacts at the University of Copenhagen. 12 native Danish speakers participated in the experiment; 2 speakers were simultaneous bilinguals (Danish/German, Danish/Turkish). Again, the speakers received a small token of thanks or a movie gift card for their participation.

\section{[3.2] Experiment design}

To elicit main and embedded clauses, the experiments included two different tasks: the transformation of main clauses into embedded clauses (see (15)), and the opposite transformation of embedded clauses into main clauses (as in (16)). All experimental items are built up in the same way: the participant is presented with a background sentence (15/16a) and is asked to read this sentence aloud. When the participant has read the background sentence, a trigger appears. This trigger is either the start of a new sentence (15b), or just a proper name (16b). The participant is tasked with completing this utterance using the words from the background sentence. Target responses are given in (15/16c), with curly 
brackets showing the placement options of the finite verb.

(15) a. (Erik:) Jag kör ofta bil till jobbet. I drive often car to work.DEF 'I often drive to work.'

b. Erik sa att... Erik said that...

c. han \{kör\} ofta $\{k o ̈ r\}$ bil till jobbet. he drives often drives car to work.DEF 'Erik says that he often drives to work.'

[background] [trigger] [response]

(16) a. Mads sagde, at han normalt hader lakrids. [background] Mads said that he usually hates liquorice 'Mads said that he usually hates liquorice.'

b. (Mads:)

[trigger] Mads

c. Jeg \{hader\} normalt \{hader\} lakrids. I hate usually hate liquorice [response] 'Usually, I hate liquorice.'

The example in (15) tests placement of the embedded finite verb with respect to the adverb ofta 'often', i.e., the possibility of embedded V2. Using the task in (16), we test verb placement in main clauses, here with respect to the adverb normalt 'usually'. The Swedish experiment included only items of the main-to-embedded type (i.e., example (15)). The Danish experiment included both transformations.

\section{[3.3] Materials}

\subsubsection{Conditions}

To examine the possibility of having embedded V2, i.e., embedded Verb > Adverb order, we set up sentences of three different clause types and with different adverbs. Three different clause types were included: assertive complements of the matrix predicate säga att/siger at 'say that', factive adjective complements of stolt över/stolt af 'proud of', and indirect yes/no questions in the complement of fraga/ undra om/spørge om 'asked whether'. EV2 is expected to be generally available in assertive complements (see (15) above); it is expected to be disfavoured in factive complements like (17) (e.g., Vikner 1995, Wiklund et al. 
2009), ${ }^{2}$ and disallowed in interrogative complements like (18) (Vikner 1995).

a. (Ellen:) Jeg kommer aldrig for sent i skole. [background] I come never too late in school 'I am never late for school.'

b. Ellen er stolt af, at... Ellen is proud of that

[trigger]

hun kkommer\} aldrig \{kommer\} for sent i skole. [response] she comes never comes too late for school

'Ellen is proud that she is never late for school.'

(18)

a. (Oscar:) Cykler Mads altid til arbejde? [background]
bikes Mads always to work 'Does Mads always bike to work?'

b. Oscar spurgte, om ...

[trigger]

Oscar asked if

Mads \{cykler\} altid \{cykler\} til arbejde.

Mads bikes always bikes to work

[response]

'Oscar asked if Mads always bikes to work.'

In Section 2.1, I pointed out that the possibility of having EV2-order may differ between adverbs; we therefore included 3 different medial adverbs in the embedded V2-items: aldrig/aldrig 'never', alltid/altid 'always' and ofta/ofte 'often'. Including different types of adverbs also allows us to further determine the landing site of the moved embedded verb. That is, although these three adverbs all occur sentence-medially, they are assumed to differ in the position they take in the functional hierarchy (Cinque 1999) which may affect the possibilities for verb movement. A split between TP-adverbials (i.e., aldrig 'never') which takes scope over the entire proposition, and lower VP-adverbials that can optionally modify the verbal predicate alone (i.e., 'always' and 'often') is also commonly assumed (cf. Jackendoff 1972).

In the experiment, the embedded V2-items alternate with items testing verb placement in embedded wh-questions (main verb: frågade/spurgte 'asked' or ville veta/ville vide 'wanted to know') or simple declaratives (main verb: är säker på att/er sikker på at 'is sure that', tror at (t) 'thinks that'). Together, these items act as fillers for the embedded V2-condition. None of the fillers included adverbs. Because no word order variation is expected in these clauses (i.e., these

[2] Julien (2007: 122-124, 2015: 166) nevertheless finds some examples of embedded V2 after factive predicates in Norwegian. She points out that the clause must be asserted for this word order to be allowed. 
embedded clauses should all have non-V2 order), they are essentially controls that can be used to test if participants understand the task of transforming main clauses into embedded clauses. A complementizer/relative marker should be produced in embedded subject wh-questions (see (19)); embedded non-subject wh-questions should lack subject-verb inversion (20). Finally, the declarative fillers should all have non-V2 order as well, see (21).

(19) Ellen spurgte, ...

Ellen asked

hvilke bands \{der\} spillede på festivalen i weekenden. [resp.] which bands cOMP played on festival.DEF in weekend.DEF 'Ellen asked which bands played the festival this weekend.'

(20) Lena undrade (vad \{köpte\} Erik \{köpte\} i affären.) [trigger \& Lena wondered what bought Erik bought in shop.DEF response] 'Lena wondered what Erik bought in the shop.'

(21) a. (Kalle:) Utflykten i morgon är inställd. (Kalle:) trip.DEF tomorrow is cancelled 'The trip tomorrow is cancelled.'

b. Kalle är säker på att ... Kalle is sure on that utflykten i morgon är inställd. trip.DEF tomorrow is cancelled [background] 'Kalle is sure that the trip tomorrow is cancelled.'

In addition to the embedded clause conditions described above, which were tested in both Danish and Swedish, the Danish experiment included two main clause conditions. In the first of these we test verb placement with respect to main clause adverbs including both regular sentence-medial 'V2-adverbs', and preverbal 'V3-adverbs' that can occur before the finite verb. The V2-adverb subcondition included the adverbs heldigvis 'fortunately', uncegtelig 'undeniably', normalt 'usually', desvcerre 'unfortunately' and noesten 'almost'. These adverbs are by default placed after the verb. The following V3-adverbs were used: mer end 'more than', simpelthen 'simply', bogstavelig talt 'literally' and ncesten 'almost' (as a verb modifying adverb). These adverbs optionally allow linear non-V2 order (i.e., Adverb > Verb) (see (22)). The adverb mer end 'more than' can only occur preverbally. 
(22) a. Mads sagde, at han simpelthen elsker marcipan. [backgr.] Mads said that he simply loves marzipan

'Mads said that he simply loves marzipan.'

b. (Mads:)

[trigger]

Jeg \{elsker\} simpelthen \{elsker\} marcipan.

I love simply love marzipan

[response]

'I simply love marzipan.'

The second main clause condition tests main clause wh-questions. This condition included both subject- and non-subject wh-questions (see (23) and (24), repectively), and furthermore always included an equal number of short (e.g., hva 'what') and long wh-expressions (e.g., hvilke barn 'which kids').

(23) a. Ellen spurgte, hvem der lavede maten.

[background] Ellen asked who that made food.DEF 'Ellen asked who made the food.'

b. (Ellen:) Hvem \{der\} lavede maten? [trigger \& response] who that made food.DEF

'Who made the food?'

(24) a. Jonas spurgte, hvad hun arbejdede på. Jonas asked what she worked on 'Jonas asked what she was working on.'

b. (Jonas:) Hvad \{arbejdede\} hun \{arbejdede\} på? what worked she worked on 'What was she working on?'

[background]

[trigger \& response]

\subsubsection{Experiments}

The Swedish experiment included a total of 72 items presented in two parts with a small break in between. Both parts use the main-to-embedded transformation (examples (17-21)), i.e., they only tested verb placement in embedded clauses. Table 2 below gives an overview of the material used in the Swedish experiment. 


\begin{tabular}{|c|c|c|c|}
\hline Part/Task & Embedded V2 & $\begin{array}{c}\text { Embedded } \\
\text { wh-questions }\end{array}$ & Fillers \\
\hline $\begin{array}{l}\text { 1. main-to- } \\
\text { embedded }\end{array}$ & $\begin{array}{c}6 \text { assertive } \\
6 \text { factive } \\
6 \text { indirect questions }\end{array}$ & $\begin{array}{c}6 \text { subject wh } \\
6 \text { non-subj. wh }\end{array}$ & 6 declaratives \\
\hline $\begin{array}{l}\text { 2. main-to- } \\
\text { embedded }\end{array}$ & $\begin{array}{c}6 \text { assertive } \\
6 \text { factive } \\
6 \text { indirect questions }\end{array}$ & $\begin{array}{c}6 \text { subject wh } \\
6 \text { non-subj. wh }\end{array}$ & 6 declaratives \\
\hline
\end{tabular}

TABLE 2: Overview of the build-up of the Swedish experiment: $72(2 \times 36)$ items.

An overview of the conditions and items in the Danish experiment is provided in Table 3. This experiment included both embedded and main clause conditions. The number of items in the embedded clause conditions differed slightly from Swedish: we included twice the number of items in the assertive verb subcondition in this experiment, as we expected the most variation in this subcategory (cf. Section 2.1). In addition, there are 8 , not 6 , embedded nonsubject wh-questions. This is the result of negligence in the design: an expletive was included in the Danish translation (25a) of one of the Swedish subject whquestions (25b), making the translation into a non-subject question.

(25) a. Hvor mange elever er der på den skole? [Danish] how many students are EXPL on this school 'How many students are there at this school?' item \#2409/2410

b. Hur många elever går på skolan? how many students go on school.DEF 'How many students go to this school?'

\begin{tabular}{cccccc}
\hline Part/Task & $\begin{array}{c}\text { Embedded } \\
\text { V2 }\end{array}$ & $\begin{array}{c}\text { Embedded } \\
\text { wh-questions }\end{array}$ & $\begin{array}{c}\text { V2 \& V3 } \\
\text { adverbs }\end{array}$ & $\begin{array}{c}\text { Main clause } \\
\text { wh-questions }\end{array}$ & $\begin{array}{c}\text { Decl. } \\
\text { filler }\end{array}$ \\
\hline $\begin{array}{c}\text { 1. main-to- } \\
\text { embedded }\end{array}$ & $\begin{array}{c}4 \text { factive } \\
4 \text { ind. ques. }\end{array}$ & $\begin{array}{c}4 \text { subject wh } \\
8 \text { non-subj. wh }\end{array}$ & & & 8 \\
& & & $8 \mathrm{~V} 2-\mathrm{adv}$ & 8 subject wh & \\
$\begin{array}{c}\text { 2. embed.- } \\
\text { to-main }\end{array}$ & & $8 \mathrm{~V}$ 3-adv & 8 non-subj. wh & 8 \\
\hline
\end{tabular}

TABLE 3: Overview of the build-up of the Danish experiment: $80(2 \times 40)$ items. 


\section{[3.4] Experimental procedure}

The experiments were run on laptops using the experimental software OpenSesame (Mathôt et al. 2012). We recorded the participants' elicited production using audio recorders (ZoomH4n, ZoomH4npro) with the inbuilt omnidirectional condenser microphone capsules or, when available, an external lapel microphone (audio-technica AT831). All the recordings were made in WAVformat ( $44.1 \mathrm{kHZ}, 16 \mathrm{bit})$. All elicited utterances were tagged for word order using the annotation software ELAN (Wittenburg et al. 2006).

A total of 5,104 sentences from the 33 native Swedish and Danish speakers participating in the experiments are available in the online Nordic Word order Database. I will discuss the patterns we find in these results in the next sections.

[4] RESUlts: VERB PLACEMENT IN SWEDISH AND DANISH EMBEDdED CLAUSES

\section{[4.1] Embedded Verb Second}

Table 4 presents the results of the embedded verb second (EV2)-condition in Swedish and Danish. There are remarkably few instances of Verb $>$ Adverb order (overall only $2.2 \%$ ), even in assertive contexts where EV2 is expected to be a grammatical alternative. It is quite surprising that the largest share of V2-orders in Swedish is produced in factive complements, and not in assertive ones. However, the actual numbers are too small to draw any clear conclusions. Moreover, examples of Norwegian and Swedish factive complements with V2 order have been found in corpora (see e.g., Julien 2007, Ringstad 2019), so this possibility is not completely unexpected.

Most of the responses marked "Other" in the table (i.e., not corresponding to one of the predicted responses) are produced in the complements of the factive adjective proud of: in these cases, either the adverb is missing, or an infinitive construction is used in the complement, as in (26).

(26) Johan är stolt över att aldrig komma för sent till skolan. Johan is proud of COMP never come.INF too late to school.DEF 'Johan is proud to never be late for school.'

[STH37] 


\begin{tabular}{cccc}
\hline Subcondition & $\begin{array}{c}\text { non-V2 } \\
\text { (Adverb > Verb) }\end{array}$ & $\begin{array}{c}\text { V2 } \\
\text { (Verb > Adverb) }\end{array}$ & Other \\
\hline Swedish & 244 & $6(2.4 \%)$ & 2 \\
\hline $\begin{array}{c}\text { assertive complement } \\
\text { factive adjective } \\
\text { complement } \\
\text { indirect question }\end{array}$ & 231 & $7(2.8 \%)$ & 14 \\
$\quad$ Danish & 247 & $4(1.6 \%)$ & 1 \\
\hline $\begin{array}{c}\text { assertive complement } \\
\text { factive adjective } \\
\text { complement }\end{array}$ & 152 & $3(1.9 \%)$ & 1 \\
indirect question & 44 & $1(1.9 \%)$ & 7 \\
\hline Total observations (\%) & $\mathbf{9 6 9 ( 9 5 . 4 \% )}$ & $\mathbf{2 2 ( 2 . 2 \% )}$ & $\mathbf{2 5 ( 2 . 5 \% )}$ \\
\hline
\end{tabular}

TABLE 4: Overview results EV2-condition: Clause type does not clearly influence the proportion of Verb > Adverb orders produced in Swedish or Danish.

Remember that three different adverbs were used in the embedded V2condition: aldrig 'never', alltid/altid 'always' and ofta/ofte 'often'. In the Danish results, the few instances of Verb > Adverb order we find are distributed evenly over the different adverbs: 1 example of EV2 with aldrig 'never', 1 with altid 'always' and 2 examples with ofte 'often'. The Swedish EV2-orders $(\mathrm{N}=18)$ are all produced with either alltid 'always' ( 8 instances) or ofta 'often' (10 instances). As discussed in Section 3.3.1, it is commonly assumed that these two adverbs (i.e., alltid, ofte and unlike aldri) can modify the predicate alone, and that they are therefore situated at the edge of VP (see Jackendoff 1972, Cinque 1999). It is possible that the finite verb moves over the low adverbs altid and ofte more easily, resulting in more Verb > Adverbs orders with these adverbs, than with the higher adverb aldri.

There is a further difference between the adverbs alltid and ofte that might play a role in the word order variation with these adverbs. Specifically, ofte can occur clause-finally in Swedish, but alltid cannot. To be sure that Verb > Adverb order with ofte is the result of verb movement to the left, and not of clause-final placement of the adverb, we need additional VP-internal material. For 4 of the 7 Verb > Adverb orders produced in the Swedish experiment, this is not the case; one such example is shown in (27). 
(27) Erik är stolt över att han cyklar alltid till jobbet. [STH37] Erik is proud over that he bikes always to work.DEF 'Erik is proud that he always bikes to work.'

The Verb > Adverb order that we find in assertive and interrogative contexts is not affected by this potential clause-final placement of the adverb. If we exclude the ambiguous examples, only $1.2 \%$ of the factive complements, on the other hand, are produced with EV2 order in Swedish.

\section{[4.2] Embedded wh-questions}

As expected, we find almost no word order variation in the embedded whquestion condition; see Table 5 for a summary of the results. The wh-questions never included adverbs and are almost all produced with non-V2 order (i.e., with both the wh-word and the subject preceding the finite verb). Only $2.2 \%$ of the produced embedded wh-questions have main clause V2 order. It seems reasonable to treat these examples as errors involving direct wh-questions (e.g., 'Mads asked: "how many students go to this school?"'). We find a few instances of cleft constructions in the Swedish results (as in (28)), but not in Danish.

(28) Karin frågade vem det var som köpte bilen.

[STH56]

Karin asked who it was COMP bought car.DEF

'Karin asked who it was that bought the car.'

Some Swedish non-subject questions include the optional complementizer som (all marked "Other" in Table 5, N =9), as in (29) below. As expected, we do not find any such examples in Danish (cf. (11) above).

(29) Erik undrade hur många fiskar som Johan fick. [STH49] Erik wondered how many fish.PL COMP Johan got 'Erik wondered how many fish Johan got yesterday.' 


\begin{tabular}{ccccc}
\hline Subcondition & Non-V2 & V2 & $\begin{array}{c}\text { Cleft } \\
\text { (non-V2) }\end{array}$ & $\begin{array}{c}\text { Other } \\
\text { (non-V2) }\end{array}$ \\
\hline Swedish & 240 & $6(2.4 \%)$ & 3 & 3 \\
\hline $\begin{array}{c}\text { subject wh-question } \\
\text { non-subject wh- } \\
\text { question }\end{array}$ & 239 & $2(0.8 \%)$ & 2 & 9 \\
$\quad \begin{array}{c}\text { Danish } \\
\text { subject wh-question } \\
\text { non-subject wh- } \\
\text { question }\end{array}$ & 45 & $3(6.3 \%)$ & 0 & 0 \\
\hline Total observations & $\mathbf{6 1 4}(\mathbf{9 4 . 8 \% )}$ & $\mathbf{1 4 ( 2 . 2 \% )}$ & $\mathbf{5 ( 0 . 8 \% )}$ & $\mathbf{1 5 ( 2 . 3 \% )}$ \\
\hline
\end{tabular}

TABLE 5: Overview Swedish and Danish results embedded wh-questions:The overwhelming majority of these clauses are non-V2 as expected.

[5] RESULTS: VERB PLACEMENT IN DANISH MAIN CLAUSES

[5.1] Sentence-medial and preverbal adverbs

Recall that we elicited production of main clauses with two types of adverbs in Danish: adverbs like mer end 'more than' and simpelthen 'simply' that can optionally occur in preverbal position (here referred to as V3-adverbs), and sentence-medial adverbs (V2-adverbs) like heldigvis 'fortunately', uncegtelig 'undeniably'. For both types of adverbs, the Verb > Adverb order provided in the background sentences was often maintained, and it is the most frequently produced word order with both types of adverbs (Table 6).

\begin{tabular}{ccc}
\hline $\begin{array}{c}\text { Produced } \\
\text { word order }\end{array}$ & V2-adverbs (\%) & V3-adverbs (\%) \\
\hline Verb > Adverb (V2) & $88(83.8)$ & $71(68.9)$ \\
Adverb > Verb (V3) & $3(2.9)$ & $12(11.7)$ \\
\hline Adverb first & $9(8.6)$ & $4(3.9)$ \\
Adverb dropped & $4(3.8)$ & $14(13.6)$ \\
Other & $1(1.0)$ & $2(1.9)$ \\
\hline Total observations & $\mathbf{1 0 5 ( 1 0 0 )}$ & $\mathbf{1 0 3 ( 1 0 0 )}$ \\
\hline
\end{tabular}

TABLE 6: Word orders produced with V2 and V3 adverbs in the Danish experiment, proportions provided in brackets.

There are three unexpected instances of non-V2 order with the sentence-medial 
adverb uncegtelig, but the majority of items with a sentence-medial adverb were produced with the standard V2 order. In the V3-adverb subcondition, only $11.7 \%$ of the produced sentences have non-V2 order. All of the V3-adverbs included in the test items were produced in V2-position at least once: mer end 'more than' (N = 8), simpelthen 'simply' (1), noesten 'almost' (2) and bogstavelig talt 'literally' (1). These V3-structures were produced by a subset of the speakers $(\mathrm{N}=6 / 12)$. The V3-adverbs simpelthen 'simply', bogstavelig talt 'literally' and noesten 'almost' are most often placed after the verb (88-92\% of items).

A lot of responses in the main clause adverb condition were unexpected or irrelevant. The "other"-response in Table 6 is therefore split into three categories: 'adverb first', 'adverb dropped' and 'other'. Though the numbers are low, it seems that if a V2-adverb is not produced in the expected position following the verb, it is most often placed sentence-initially (as in (30)).

(30) Normalt hader jeg spegesild. normally hate I salted.herring

'Normally, I hate salted herring.'

The adverb mer end 'more than', i.e., the only adverb that must occur in preverbal position, is often dropped altogether (61.5\% of responses). Danish participants clearly prefer to stick to the standard V2 word order even when non-V2 is an available option.

\section{[5.2] Main clause wh-questions}

Finally, we tested Danish main clause wh-questions. All the utterances in this condition were produced with the standard verb second word order. In the only deviation from the target response, a participant changed a word in the sentence. This example still had V2 order.

\section{[6] Discussion}

In this article, I have studied the placement of the finite verb in four constructions: in embedded and main clause wh-questions, in embedded clauses with respect to adverbs (embedded V2) and with respect to different types of adverbs in main clauses. The research is part of a larger project, the Nordic Word order Database (NWD; Lundquist et al. 2019) and the same experiments have been run in Norway and on the Faroe Islands as well. I will now highlight some of the more striking results from the Swedish and Danish results and compare these with results from the other North Germanic languages.

Many of the results from the Swedish and Danish experiments are as expected and follow the standard V2-pattern of the respective languages (i.e., V2 in main 
clauses and non-V2 in embedded clauses). Viewed together, Swedish and Danish embedded wh-questions are produced with non-V2 order in $98 \%$ of the responses. In the Danish main clause wh-condition, we find that all the responses have standard V2 word order. In this respect, Danish is clearly different from Norwegian where approx. $15 \%$ of all main clause wh-questions were produced with non-V2 order in the Nordic Word order Database (NWD) results (Westendorp 2021: 27-29).

The results in the other two test conditions require further exploration. First of all, we find strikingly few examples of embedded V2 in our results. Based on existing literature, I hypothesised that participants would produce EV2 orders in assertive, but not in factive or interrogative complements (Section 3.3.1). However, even in the complement of the assertive verb 'say', only $2 \%$ of the items were produced with embedded Verb $>$ Adverb order in both Swedish and Danish. This is especially surprizing as almost half of the complement clauses with negation in the spoken Danish LANCHART corpus have V2-order (Jensen \& Christensen 2013). However, the numbers in the present study are similar to the numbers that Heycock et al. (2012) find for written (newspaper) Danish (2012: 569). It may be the case that the context of our experiments (i.e., the semantic conditions or the (perceived) register) is not suitable for embedded V2. Yet, results in the NWD from Faroese show that Faroese speakers have no issues with producing embedded V2 in the same experimental paradigm: In Faroese, 40.7\% of the assertive complements have Verb > Adverb order (Westendorp 2020: 37). It is possible that Swedish and Danish, but not Faroese, require a different, and specific, pragmatic context to allow for embedded V2. We must also remember that even when EV2 is acceptable in Swedish and Danish (and Norwegian), it is not always produced or preferred. Surprisingly, the Norwegian NWDparticipants also produce more EV2 orders than the Swedish and Danish participants (11.2\% EV2 in assertive complements; see Westendorp 2021: 22). We may suspect that even within Mainland North Germanic, varieties differ in subtle ways in their possibilities for verb movement. In this vein, Bentzen (2005) has previously argued that Northern Norwegian allows for V-to-I movement of the embedded finite verb to a lower inflectional position. However, we have no way of checking if this accounts for the difference between the MNG varieties in the NWD-data, and it largely remains an open question. In this data set, Swedish and Danish speakers have in common that they show no clear effect of clause type (assertive/factive/interrogative complements) in the production of EV2. In this respect, these speakers are clearly different from the Faroese and Norwegian participants, where we do find that clause type is an important factor influencing the production of EV2. 
A second unexpected finding concerns the main clause adverb condition. In this condition, Danish speakers most often produce V2-word order even with adverbs that may occur preverbally (11.7\% Adverb > Verb vs. $68.9 \%$ Verb > Adverb). Moreover, the non-V2 orders with preverbal adverbs that we do find are only produced by a subset of the participants. Again, the Danish participants differ remarkably from the Norwegian speakers in the Nordic Word order Database: the Norwegian speakers placed V3-adverbs in preverbal position in 41.5\% of the cases (Westendorp 2021: 25). Although all four of the Danish preverbal adverbs that were included in the experiment are possible in the second position of the clause, Danish speakers are less prone to step away from a V2-pattern. Possibly, Danish and Norwegian differ in the semantic or perhaps the prosodic restrictions on preverbal placement of adverbs. There is currently ongoing work to analyze the prosodic units in the NWD-material, so comparisons between the languages can hopefully be made soon.

Finally, there are some apparent shortcomings in the set-up of the experiments in this article that should be mentioned. On the one hand, considerably fewer Danish speakers than Swedish participated in the experiment. This is the result of limitations on time and resources. One might wonder if it is correct to compare the results from the two languages considering this discrepancy. On the other hand, a comparison is only made for the embedded conditions and the results in these conditions are more or less categorical. Most likely, the overall results for the Danish embedded clauses would not change even if more Danish speakers were included. Connected to this issue, it is of course a clear drawback of the experimental set-up that main clauses were not tested in Swedish.

It would furthermore be a welcome extension of the experiment to include the negative adverb inte/ikke 'not' in the embedded V2-condition. There are two main reasons why this addition could be worthwhile. First, it has been shown for several varieties of North Germanic that the possibilities of movement of the embedded verb over adverbs may differ from the movement over negation (cf., Section 2.1). Second, it has been argued in the literature that negation is the only unambiguous marker of the left edge of VP (see e.g., Falk 1993: 171-72; Koeneman \& Zeijlstra 2014). If this is indeed the case, Verb > Adverb order with adverbs other than negation should be treated as involving V-in situ, not EV2.

The Norwegian experiment for the NWD-project did in fact include negation in addition to the adverbs always, often and never. Speakers produced embedded V2 orders with all adverbs, also with ikke 'not' (Westendorp 2021: 19f.). Specifically, 7.5\% of the assertive complements with negation had Verb $>$ Adverb order, more than with the adverb aldri 'never' (3.1\%), but less than the overall 
percentage of EV2 in assertive complements (11.2\%). We could possibly envisage a different pattern in Swedish or Danish if we were to include negation in those experiments. Nevertheless, I take the Norwegian result as an indication that Verb > Adverb orders with the adverbs always, often and never, as well as Verb > negation orders are instances of EV2, provided of course that there is internal VP-material to rule out clause-final placement of the adverb.

\section{AC KNOWLEDGMENTS}

This research was funded by the Research Council of Norway (RCN) project 'Variation and Change in the Scandinavian Verb Phrase' (project number: 250755, PI: Ida Larsson), which covered expenses associated with fieldwork and project development. Westendorp was also funded through her PhD project at UiT The Arctic University of Norway. All the fieldwork that resulted in this paper was carried out together with Eirik Tengesdal. We would like to thank Janneke Walin and NTI Gymnasiet Sollentuna, Gunnel Thydell at Anna Whitlocks Gymnasium and Stockholm University for hosting us for the Swedish fieldwork. Thanks also to Johan Brandtler, Lars Fant and Annika Johansson at Stockholm University for assisting us in recruiting participants. This work would not have been possible without the generous help of Sofie Ol Winkler who spent considerable time translating the Danish experimental items; Svend Skriver, Janus Spindler Møller, Torben Jul Jensen and Tanya Karoli Christensen who helped us recruit Danish participants; and Københavns Universitet, Frederiksværk Gymnas and Mette Karmann who hosted us for the Danish fieldwork. We also thank all the Swedish and Danish participants who gave of their time to work with us. I am grateful for the helpful comments and feedback on various drafts of this article from two NALS referees and editors of this issue. All remaining mistakes are of course mine.

\section{REFERENCES}

Allan, Robin, Philip Holmes \& Tom Lundskaer-Nielsen. 1995. Danish: A Comprehensive Grammar. Routledge.

Andersson, Lars-Gunnar. 1975. Form and function of subordinate clauses. Doctoral dissertation, University of Gothenburg.

Bentzen, Kristine. 2005. What's the better move? On verb placement in Standard Nand Northern Norwegian. Nordic Journal of Linguistics 28(2). 153-188.

Bentzen, Kristine, Gunnar Hrafn Hrafnbjargarson, porbjörg Hróarsdóttir \& Anna-Lena Wiklund. 2007. The Tromsø Guide to the Force Behind V2. Working Papers in Scandinavian Syntax 79. 93-118. 
Bentzen, Kristine, Piotr Garbacz, Caroline Heycock \& Gunnar Hrafn Hrafnbjargarson. 2009. On variation in Faroese verb placement. Nordlyd 36(2): NORMS Papers on Faroese. 78-102.

den Besten, Hans. 1983. On the interaction of root transformations and lexical deletive rules. In W. Abraham (ed.), On the Formal Syntax of the Westgermania, 47-131. John Benjamins Publishing Company.

Brandtler, Johan. 2020. Vi bara testade en hypotes... Norsk Lingvistisk Tidsskrift 38. 59-92.

Brandtler, Johan \& David Håkansson. 2017. V2 eller V3? Om preverbal placering av adverbial i svenskan. Norsk Lingvistisk Tidsskrift 35. 11-26.

Cinque, Guglielmo. 1999. Adverbs and functional heads: A cross-linguistic perspective. Oxford University Press.

Falk, Cecilia. 1993. Non-referential subjects and agreement in the history of Swedish. Lingua 89(2-3). 143-180.

Gärtner, Hans-Martin. 2019. On the Rich Agreement Hypothesis and varieties of embedded V2. Nordic Journal of Linguistics 42(2). 209-225.

Hansen, Erik \& Lars Heltoft. 2011. Grammatik over det Danske Sprog. Syddansk Universitetsforlag.

Heycock, Caroline, Antonella Sorace \& Zakaris Svabo Hansen. 2010. V-to-I and V2 in Subordinate Clauses: An Investigation of Faroese in Relation to Ice-landic and Danish. The Journal of Comparative Germanic Linguistics 13. 61-97.

Heycock, Caroline, Antonella Sorace, Zakaris Svabo Hansen, Frances Wilson \& Sten Vikner. 2012. Detecting the Late Stages of Syntactic Change: The Loss of $\mathrm{V}$-to-T in Faroese. Language 88(3). 558-600.

Jackendoff, Ray. 1972. Semantic interpretation in Generative Grammar. Current Studies in Linguistics Series. MIT Press.

Jensen, Torben Juel \& Tanya Karoli Christensen. 2013. Promoting the demoted: The distribution and semantics of "main clause word order" in spoken Danish complement clauses. Lingua 137. 38-58.

Julien, Marit. 2007. Embedded V2 in Norwegian and Swedish. Working Papers in Scandinavian Syntax 80. 103-161. 
Julien, Marit. 2015. The force of V2 revisited. The Journal of Comparative Germanic Linguistics 18. 139-181.

Julien, Marit. 2018. Om preverbale adverbialer. Norsk Lingvistisk Tidsskrift 36. 161178.

Jørgensen, Henrik. 2014. Adverbiernes rækkefølge i henhold til Mikkelsen. In Ole Togeby, Sten Vikner and Henrik Jørgensen (eds.), Problemer og perspektiver $i$ dansk syntaks - med Kristian Mikkelsen som anledning, 90-115. Syddansk Universitetsforlag.

Koeneman, Olaf \& Hedde Zeijlstra 2014. The Rich Agreement Hypothesis rehabilitated. Linguistic Inquiry 45. 571-615.

Lohndal, Terje, Marit Westergaard \& Øystein A. Vangsnes. 2020. V2 in Norwegian: variation and acquisition. In Sam Wolfe and Rebecca Woods (eds.), Rethinking Verb Second, chap. 33, 770-789. Oxford University Press.

Lundskær-Nielsen, Tom \& Philip Holmes. 2011. Danish: An Essential Grammar. Taylor \& Francis Group.

Lundquist, Björn. 2018. Mer om de preverbala adverbialens syntax, semantik och prosodi. Norsk Lingvistisk Tidsskrift 36. 179-195.

Lundquist, Björn, Ida Larsson, Maud Westendorp, Eirik Tengesdal \& Anders Nøklestad. 2019. Nordic Word Order Database: Motivations, Methods, Material and Infrastructure. Nordic Atlas of Language Structures (NALS) Journal 4(1). 1-33.

Mathôt, Sebastiaan, Daniel Schreij \& Jan Theeuwes. 2012. OpenSesame: An opensource, graphical experiment builder for the social sciences. Behavior Research Methods 44(2). 314-324.

Nimb, Sanni. 2004. Danske adverbier mellem leksikon og syntaks. Doctoral dissertation, University of Copenhagen.

Platzack, Christer \& Anders Holmberg. 1989. The role of AGR and finiteness. Working Papers in Scandinavian Syntax 43. 51-76.

Ringstad, Tina Louise. 2019. Distribution and function of embedded V-Neg in Norwegian: A corpus study. Nordic Journal of Linguistics 42(3). 329-363.

Stroh-Wollin, Ulla. 2002. Som-satser med och utan som. Doctoral dissertation, Uppsala University. 
Sundquist, John D. 2003. The Rich Agreement Hypothesis and Early Modern Danish Embedded-Clause Word Order. Nordic Journal of Linguistics 26(2). 233258.

Teleman, Ulf, Staffan Hellberg, \& Erik Andersson. 1999. Svenska Akademiens grammatik. Svenska Akademien. Norstedts.

Vikner, Sten. 1995. Verb Movement and Expletive Subjects in the Germanic Languages. Oxford University Press.

Wiklund, Anna-Lena, Kristine Bentzen, Gunnar Hrafn Hrafnbjargarson \& porbjörg Hróarsdóttir. 2009. On the Distribution and Illocution of V2 in Scandinavian That-Clauses. Lingua 119(12). 1914-1938.

Wiklund, Anna-Lena, Gunnar Hrafn Hrafnbjargarson, Kristine Bentzen \& porbjörg Hróarsdóttir. 2007. Rethinking Scandinavian verb movement. The Journal of Comparative Germanic Linguistics 10. 20-233.

Wittenburg, Peter, Hennie Brugman, Albert Russel, Alex Klassmann \& Han Sloetjes. 2006. ELAN: a Professional Framework for Multimodality Research. In Nicoletta Calzolari et al. (eds.), Proceedings of LREC 2006, Fifth International Conference on Language Resources and Evaluation, 1556-1559. European Language Resources Association (ELRA).

Westendorp, Maud. 2020. Verb placement in embedded sentences in Faroese. Nordic Atlas of Language Structures (NALS) Journal 5(1). 28-42.

Westendorp, Maud. 2021. Variable Verb Second in Norwegian main and embedded clauses. Nordic Atlas of Language Structures (NALS) Journal 6(1). 1-48.

CONTACT

Maud Westendorp

UiT The Arctic University of Norway

maud. westendorp@uit.no 